\title{
Designing bio-inspired adaptive climatic façades and its effect on daylighting performance of building
}

\author{
A'laa Ahmed ${ }^{\# 1}$, Ehab Okba ${ }^{* 2}$, Eman Badawy ${ }^{\# 3}$ \\ Architecture Department ${ }^{1}$, Architecture Department ${ }^{2}$, Architecture Department ${ }^{3}$. \\ Fayoum University, El-Fayoum, Egypt. ${ }^{1}$, Fayoum University El-Fayoum, Egypt. ${ }^{2}$, \\ Bine Suef University El- Bine Suef, Egypt. ${ }^{3 .}$ \\ El-Fayoum, Egypt. Bine Suef, Egypt. \\ 1.asm11@fayoum.edu.eg \\ 2 emo00@fayoum.edu.eg \\ 33eba00@fayoum.edu.eg
}

Abstract - new architectural trends have emerged to meet human needs at the present time, including architecture that is responsive / adaptive to the surrounding conditions such as climate to maximize the efficiency of the building and human comfort.

Accordingly, adaptive façades aim to change the shape of the building skin to meet users 'needs and maximize the efficiency of building's operation.

This research aims to work out a methodology to evaluate the effect of adaptive facades on daytime performance, by studying the principles and methodology of designing climate adaptation interfaces that are inspired by the biological nature, and applying the evaluation methodology to buildings that follow the principles of conditioning. The study concluded to; Buildings did not achieve the level of the ecosystem as this level should be applied to the urban design rather than architectural

In case study; Al Bahr Towers achieved $86 \%$ of the day lighting performance, while Council House 2 achieved a $69 \%$ of day lighting performance. The Syracuse University Research Center achieved $92 \%$ of day light performance. The One Ocean Expo achieved a day performance of $83 \%$.

Keyword - Adaptive façades1; Biomimicry2; Daylighting performance3

\section{INTRODUCTION}

Façades play a major role in daylight control, in addition to its importance in determining the personality of the building and users.

it also helps to reduce energy use in lighting, as it affects both heating and cooling loads, thus it is an indicator of efficient energy design. In addition, daylight provides comfort. These factors reflect the efficiency of daylight performance of the building.

Systems in nature provide a large database of strategies and mechanisms that can be achieved in the design of buildings inspired by nature. As a result of similarities between buildings and living organisms, adaptation methods in nature can be applied to buildings' façades that they can adapt to surrounding environmental changes.

Adaptive architecture is defined as the architecture in which specific building components can adapt to changing influences, such as user inputs and environmental aspects. . [1] In order to determine the method and extent of expansion of adaptive properties in adaptive buildings, building systems are classified into building components. After that, building components can be divided into elements [2].

\section{DEFINITION OF ADAPTIVE FAÇADES}

López defined adaptive façades as being responsive to changing environmental conditions, both internal and external, with internal environmental management. And can change over time through adaptation strategies to anticipate external environmental differences, as well as internal activities and interactions with populations. [3]

Loonen defined adaptive façades as having the ability to change some of their functions, features or behaviour over time, and to reflect them in response to changing performance requirements and changing conditions in order to improve the overall performance of the building. [4]

A. principles of Adaptation inspired by nature in the design of façades

Flexible systems inspired by the basic principles of adaptation can be described as in (Figure 1) [5]. 


\section{Adaptability}

- Is the ability of a system to provide certain functions taking into account multiple criteria under variable conditions through design variables that change their physical value over time.

\section{Multi-ability}

- having performance requirements but not synchronized, or having to achieve new roles over time.

- Spatial diversity at the same moment as the characteristics of the elements of building's cover vary according to its location.

\section{Evolvability}

- Flexibility in different systems to deal with different long-term conditions.

Figure 1. Principles of Adaptation inspired by nature in the design of façades (Source: researcher from [4], [6], [4])

\section{B. Factors affecting the characteristics of adaptive façades}

Adaptive façades are affected by many factors. These factors are divided into factors specific to climatic conditions of a site where this building is located, as well as the choices and preferences of users within these buildings [6].

\section{Response time}

Response time: The time range in which changes occur in an adaptive façade effectively, and effects that can be realized only during the lifetime of the entire building [7].

The following are the time ranges during which change occurs [4],or adaptations in façades as in (Figure 2) which depends on several factors: speed, formation, and mass [8]

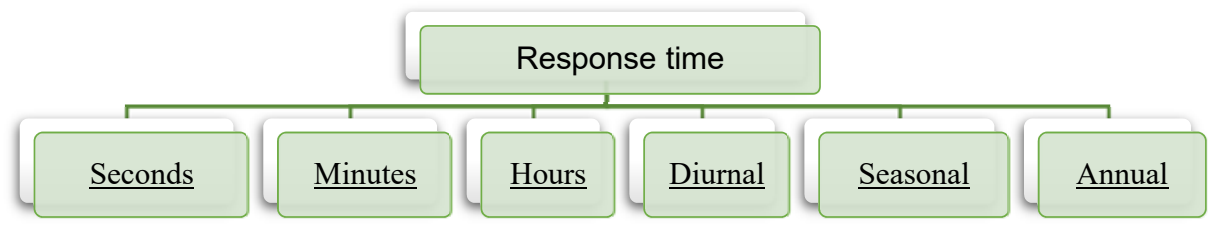

Figure 2. Response time (Source: researcher from [4]

\section{Scales of adaptation:}

It is called spatial scale which is used to indicate the size of the façades system. [4] These levels are divided into:

- Macro scale: The change in the entire building's façade is called the (kinetic façades), and movement is noticeable at the level of the entire façades through (Figure 3).

- Micro scale: occurs at the level of the internal structure of materials. Either through changes in thermal properties, non-transparent optical properties, or by changing the energy state of the composition of the material..

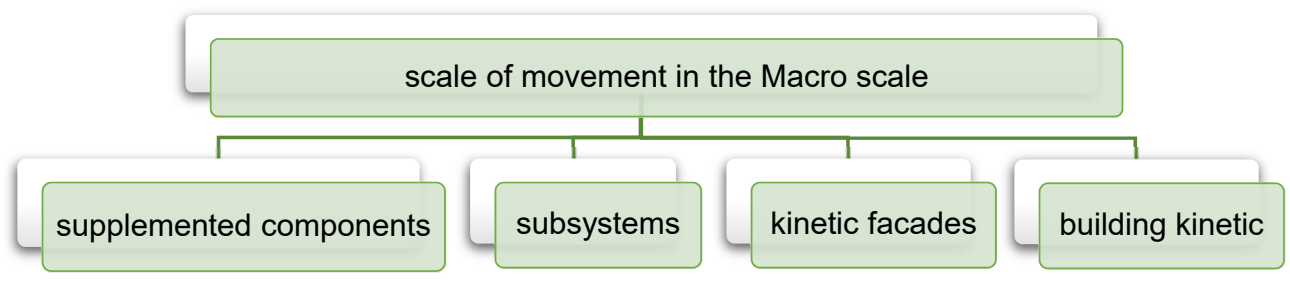

Figure 3. scale of movement in the Macro scale (Source: researcher from [4])

\section{E. Typologies of movement in adaptive façades}

- Motion patterns in adaptive façades can be categorized into five types (Figure 4). These patterns are always associated with the overall level of adaptation [9]. 


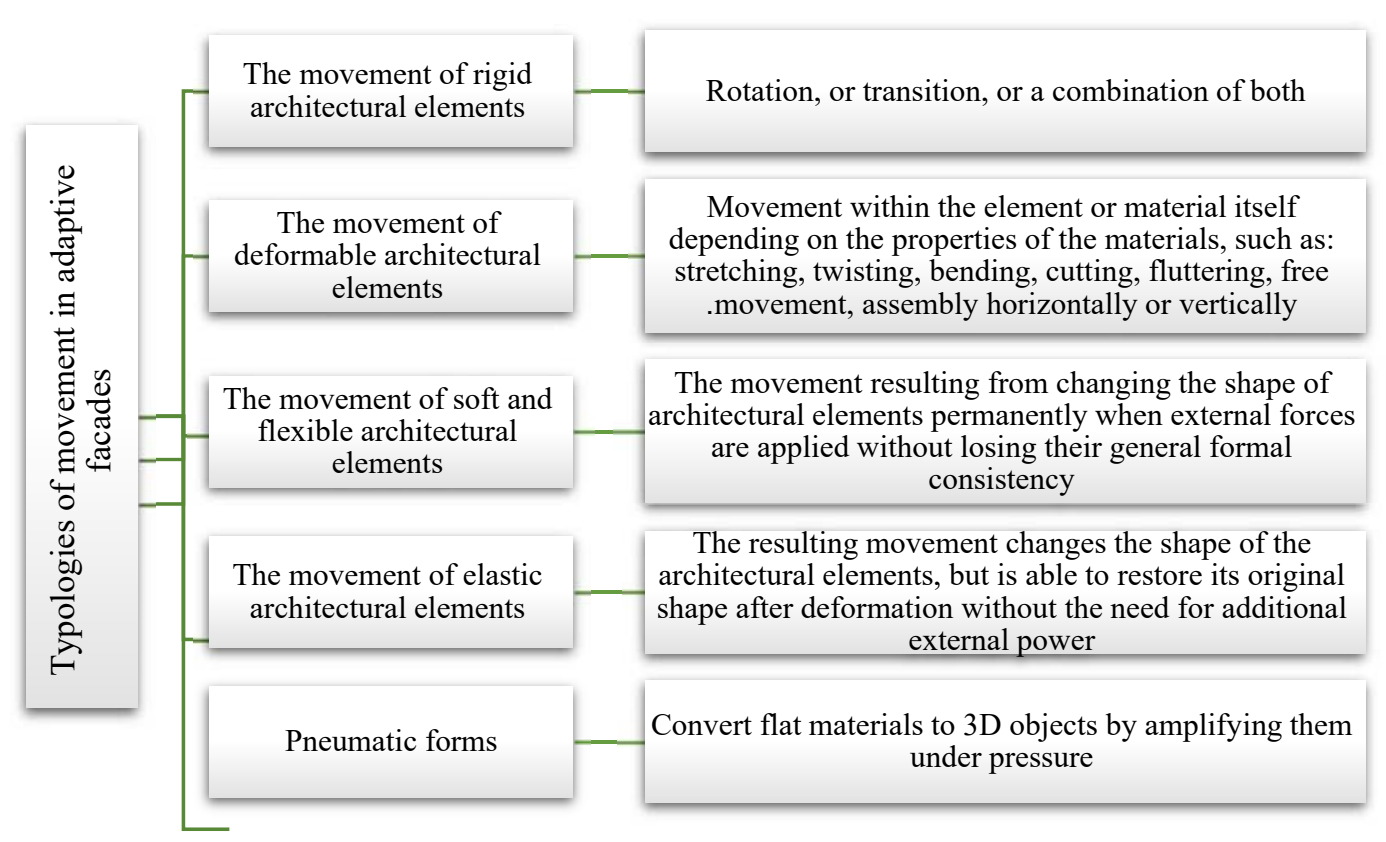

Figure 4. Typologies of movement in adaptive façades

(Source: researcher from [9])

\section{F. Biomimicry}

Nature is the primary source of inspiration for the provision of biological solutions for adaptation. At present, biology is no longer just a research trend for biologists, but a new inspiration for technological thinking. Some of these studies have considered nature as a source of inspiration for their application to architecture. Adaptation of an organism in its environment can be compared with the harmonious relationship of the building with its surroundings and its suitability for the different purposes it targets. Systems in nature provide a large database of strategies and mechanisms that can be implemented in the design of nature-inspired buildings. [3]

There are a large number of organisms that provide sources of inspiration such as bacteria, aquatic animals, seashells, birds, etc. as in (Figure 5), and can be applied in different ways by transferring their properties, shape, or behaviour [10].

\section{An overview of the various living creations as a source of inspiration in nature}
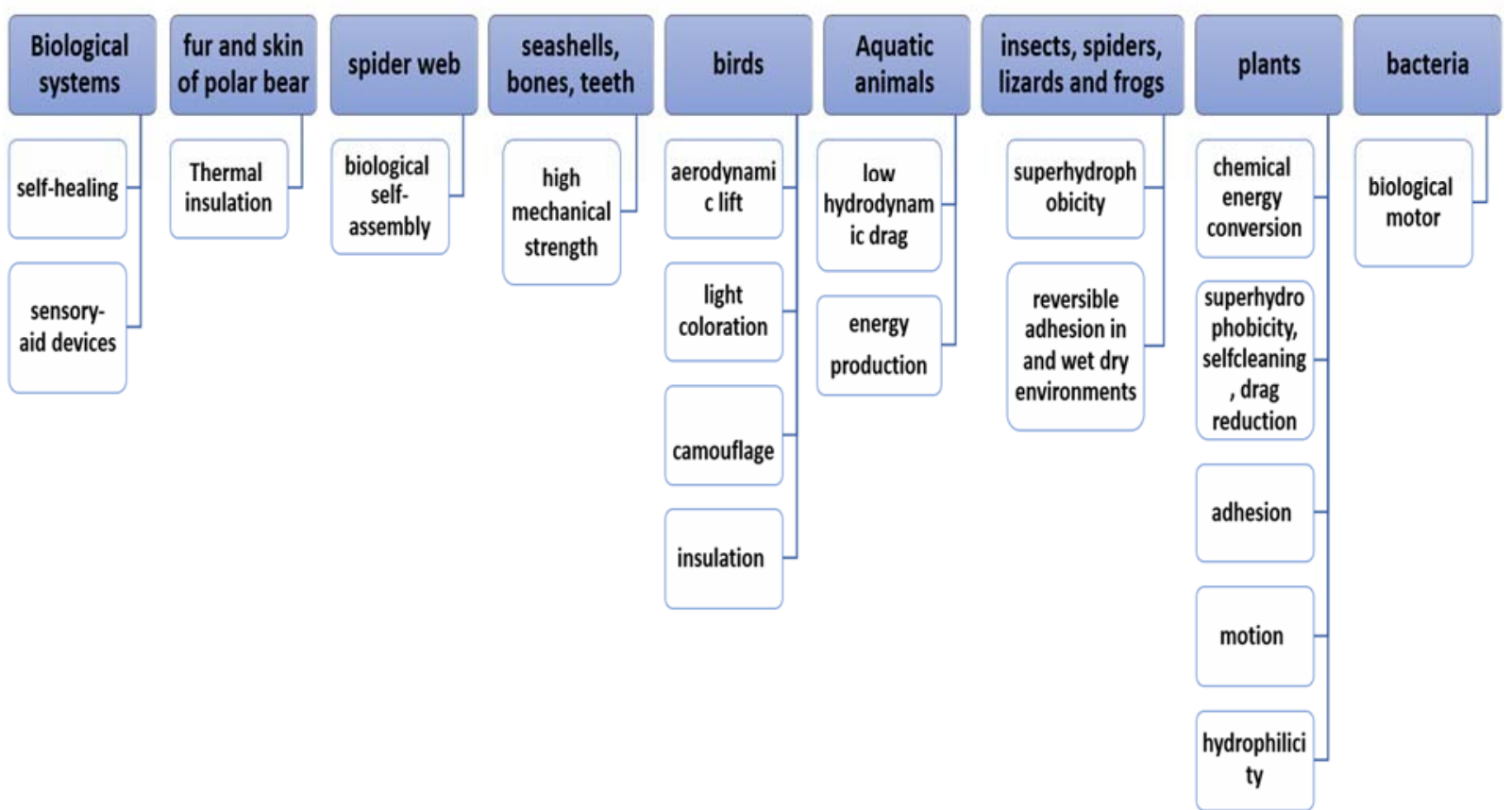

Figure 5. An overview of various living creations as a source of inspiration in nature (source: [10]) 


\section{DAYLIGHTING PERFORMANCE:}

Daylight should be taken into consideration since the beginning of the design of building as a natural lighting solution strategy and architectural design strategies are inseparable.

Day performance should be defined from different perspectives to understand the importance of daylight and the role it plays. and that is through: [11]

- Architectural Perspective: The interaction between natural light and construction to provide a pleasant, healthy and visually productive internal environment.

- $\quad$ Lighting Energy Saving Perspective: Replacing the indoor luminous environment with daylight, resulting in lower annual energy consumption of lighting.

- Energy consumption perspective in the building: the use of lighting systems and control of electrical lighting to reduce energy demand, as well as heating and cooling loads during the operation of the building.

- Cost Perspective: Reduce operating costs and maximize production through daylight strategies.

The parameters influencing the daylighting performance are divided into independent factors which are specific to the factors affecting the availability of natural light within a building, And variable factors or variables that are specific to the daytime management variables of the building as in (Figure 6) [12].

\begin{tabular}{l} 
Independent variables \\
\hline - Climate \\
- Latitude \\
-Obstructions and reflections on \\
site \\
- Building design \\
- Geometry \\
- Material properties \\
- Windows and skylights \\
- Orientation \\
- Glazing dimensions \\
- Glazing transmittance \\
- Shading \\
- Position
\end{tabular}

\section{Daylighting performance parameters}

-Visual Comfort \& Performance
- Illuminance
-Distribution
- Glare
-Direction

-Visual amenity

-outside view

-appearance

-apparent brightness

-color

- privacy

-social behavior

-health

•thermal comfort

-Device characteristics

-building energy use

-lighting energy

Figure 6. Parameters influencing daylighting performance [12].

\section{ANALYTICAL STUDY}

The analytical study dealt with architectural models in different climatic conditions and its biological solutions inspired by elements in nature from different environments. The size and scale of the adaptive element varied between the façade as a whole, the subsystems and the supplemented components, depending on the sensors and motors needed, the design and configuration, the materials used and Daylighting for each building.

\section{A. Al Bahr Towers}

The towers depend on two principles inspired by nature in the process of adapting them: the adaptability and multi-ability, The spatial diversity of the folding Origami Umbrellas movement, which is based on the HMI program [13], is the development of Siemens in the movement of these umbrellas with an external central control system, which occurs every 15 minutes [14].

The biomimicry of these towers is based on simulation of the structure of the honeycomb and its six-edged cells [15], and the simulation of flowers in their susceptibility to climatic conditions [13].

Principles of adaptation inspired by nature and factors affecting adaptive elements affect the daylighting performance of the towers rather than the biomimicry effects.

The following (Figure 7) illustrates the most important factors affecting the adaptation of the façades and the process of achieving the daylighting performance of Al Bahr Towers. 


\section{B. Council House (CH2)}

The building is designed based on the biomimicry of the termite and plant parts, and the skin achieves thermal comfort and natural ventilation (Hes). The moving west façade, which is based on the principle of adaptability, adapts to high solar radiation. Where, the moving units respond to the intensity of solar radiation at the moment at each stage of its movement.

The control within the building is based on the Building Management System (BMS) [16], an external central control system.

Principles of adaptation inspired by nature and factors affecting adaptive elements greatly affect the daylighting performance of $(\mathrm{CH} 2)$ in terms of visual comfort and performance, visual quality and energy consumption. Biomimicry is more likely to affect natural ventilation, air purification, thermal comfort and energy-saving adaptations.

The following (Figure 8) are the main factors influencing the adaptation of the façades and the process of achieving the daylighting performance of $(\mathrm{CH} 2)$.

\section{The Syracuse (CoE)}

The building includes a system of cooling and heating and a rainwater collection system. The Integrated Concentrating Solar Façade (ICSF) is applied in a small part of the southern façade to obtain radiation and convert it into thermal and electrical energy. The façade system provides power and thermal energy and enhances daytime lighting at the same time.

The solar interface depends on the principle of adaptability. This is noticed in the movement of capacitors between the glass panels in the façade, which depends on the movement of sensors on the movement of the sun with an external central control. The biomimicry in ICSF simulates the human sweating system in temperature regulation and simulates sun tracking in the sunflower flower.

The façade mainly depends on the factors affecting adaptive elements in the daylighting performance of the interface in terms of comfort and visual performance, visual amenity, and energy consumption, While Principles of adaptation inspired by nature and biomimicry affect the energy performance of the building.

The following (Figure 9) illustrates the most important factors affecting the adaptation of the solar façades and the day-to-day performance process

\section{One Ocean, Thematic Pavilion EXPO 2012}

The building's kinetic façades adapt to the strong winds in the coastal location of the project and the intensity of the lighting inside the building [17].

The adaptive interface depends on the adaptability principle in the motion of the bending panels to meet the lighting and ventilation requirements in the project lobby, which is based on an external central control system via Bus-System [18].

The idea of biomimicry of this interface is based on the simulation of the mechanism of exchange of gases in aquatic organisms, and the curving of petals of the flower of Paradise when the birds landing on them.

Principles of adaptation inspired by nature influence the design of façades, and the factors influencing the adaptive elements greatly affect daylighting performance in terms of comfort, visual performance, and energy consumption. While biomimicry affects the natural ventilation process and provide energy for adaptations.

The following (Figure 10) shows the most important factors affecting the adaptation of the façades and the process of achieving the daylighting performance.

The following (Table 1) shows a comparison between case studies how they achieved the bio-inspired adaptive façades. Then (Table 2) shows comparison between case studies about the daylighting performance. And Finally, (Table 3 ) shows comparison between case studies about the relation between adaptive façades and the daylighting performance. 


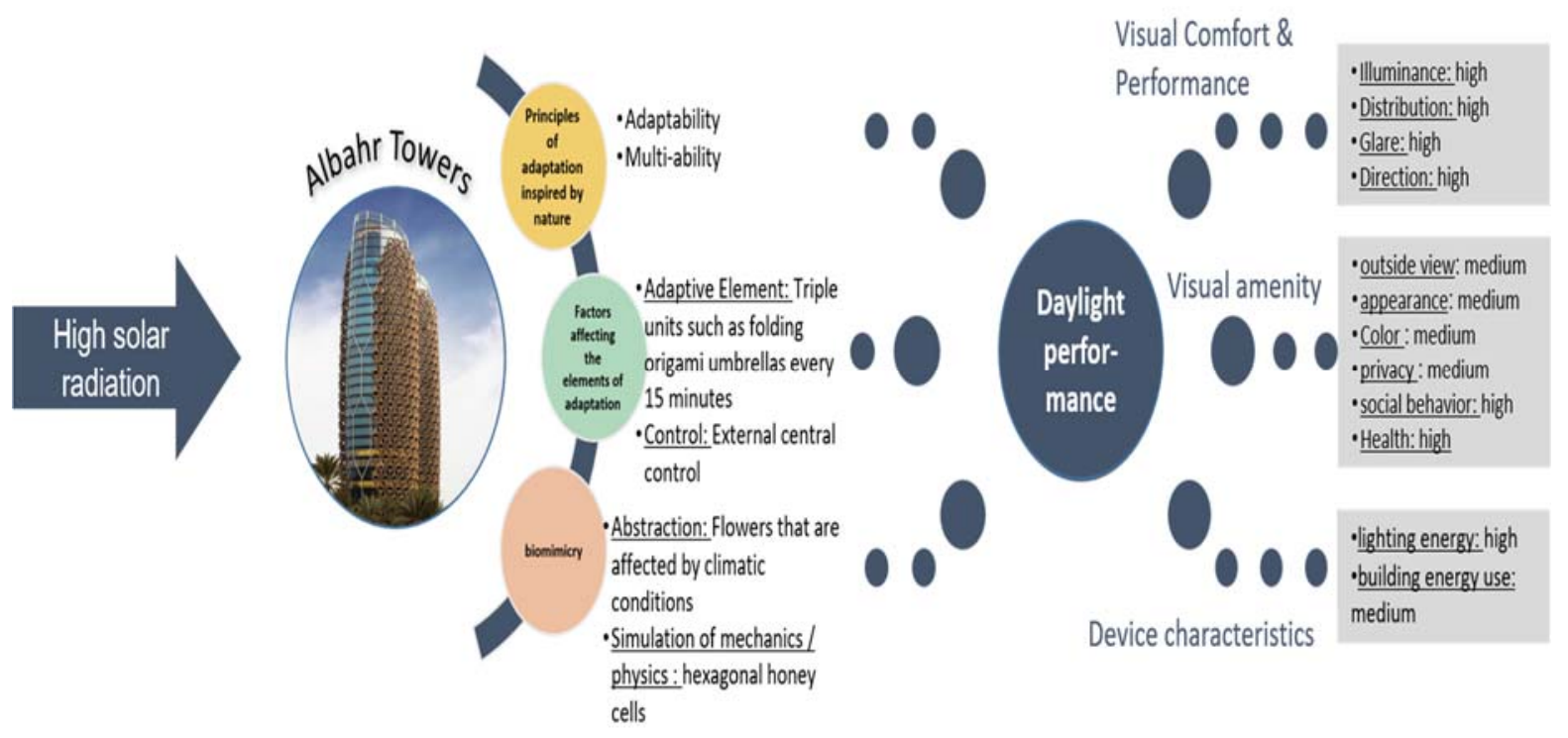

Figure 7. Daylight performance process in Al Bahr Towers (Source: researcher)

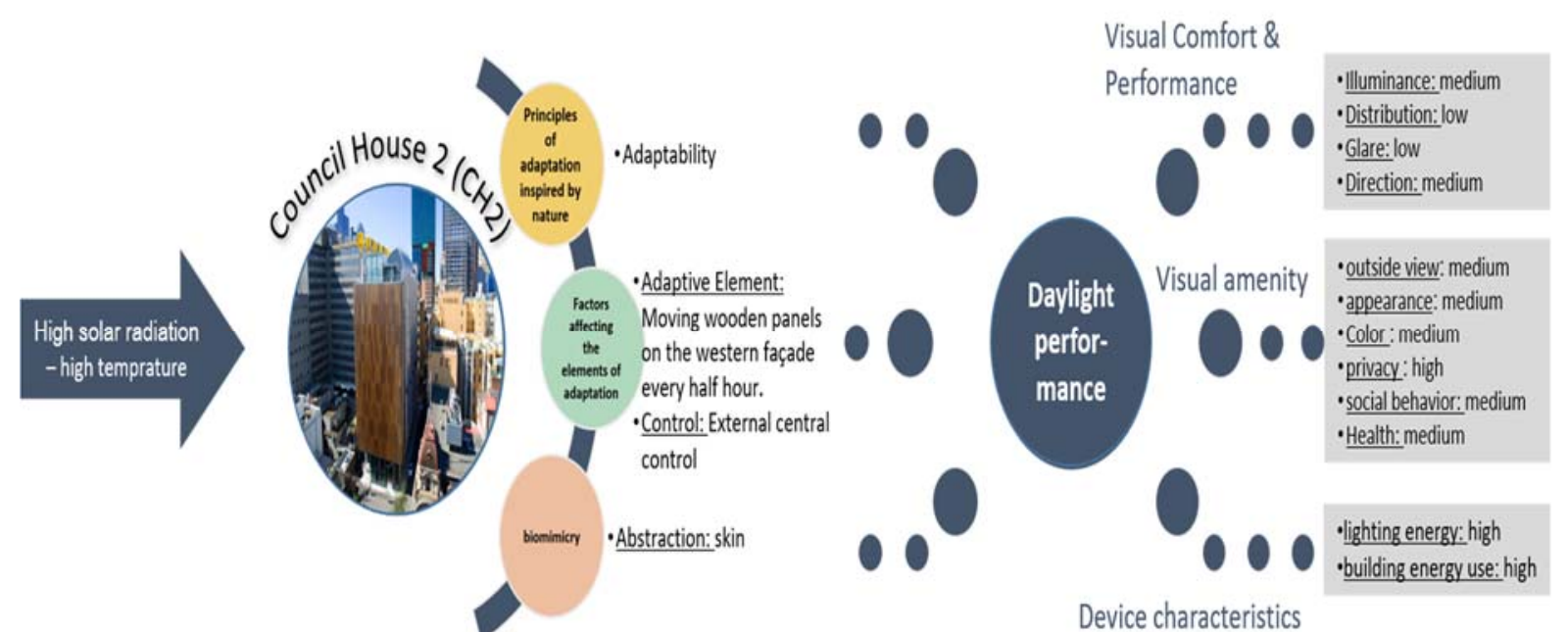

Figure 8. Daylight performance process in $\mathrm{CH} 2$ (Source: researcher)

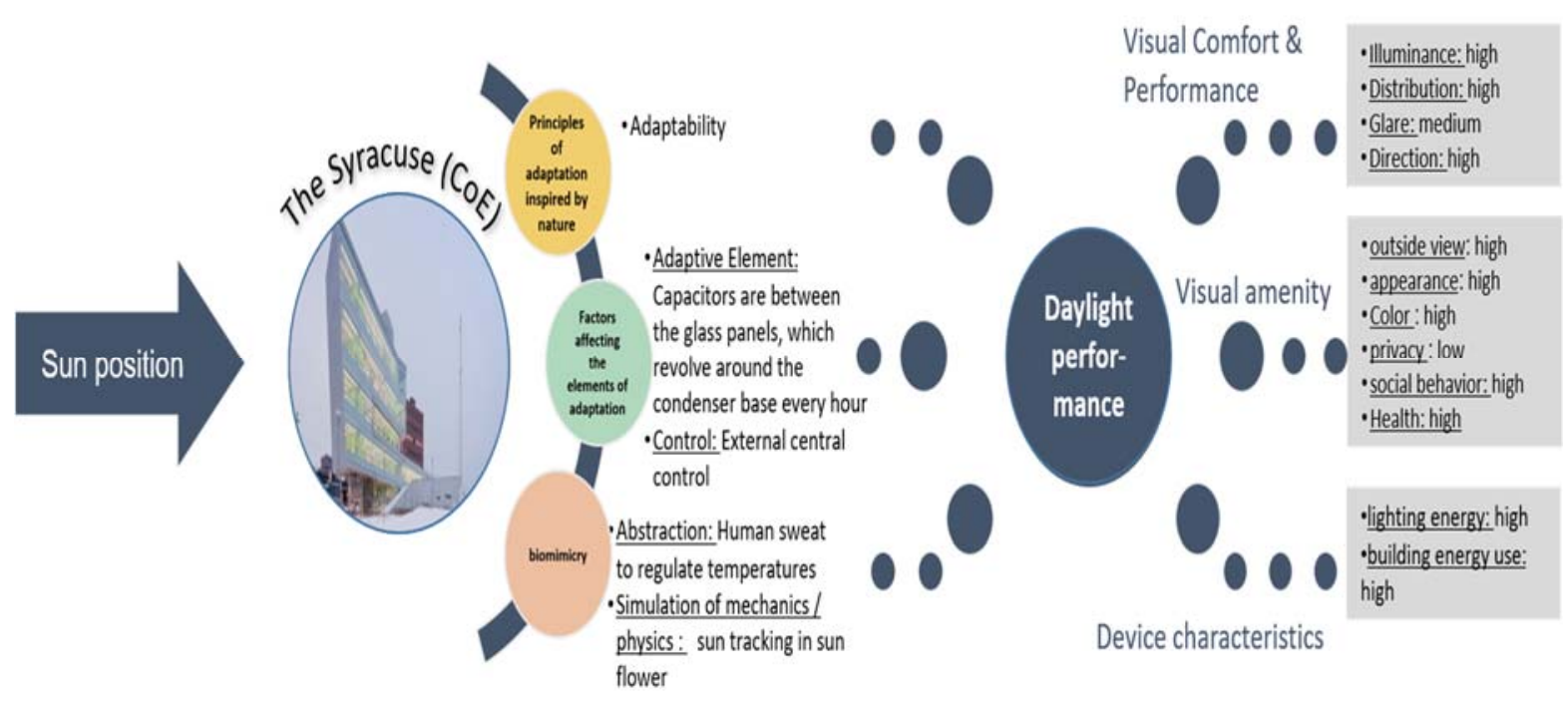

Figure 9. Daylight performance process in $\mathrm{CoE}$ (Source: researcher) 


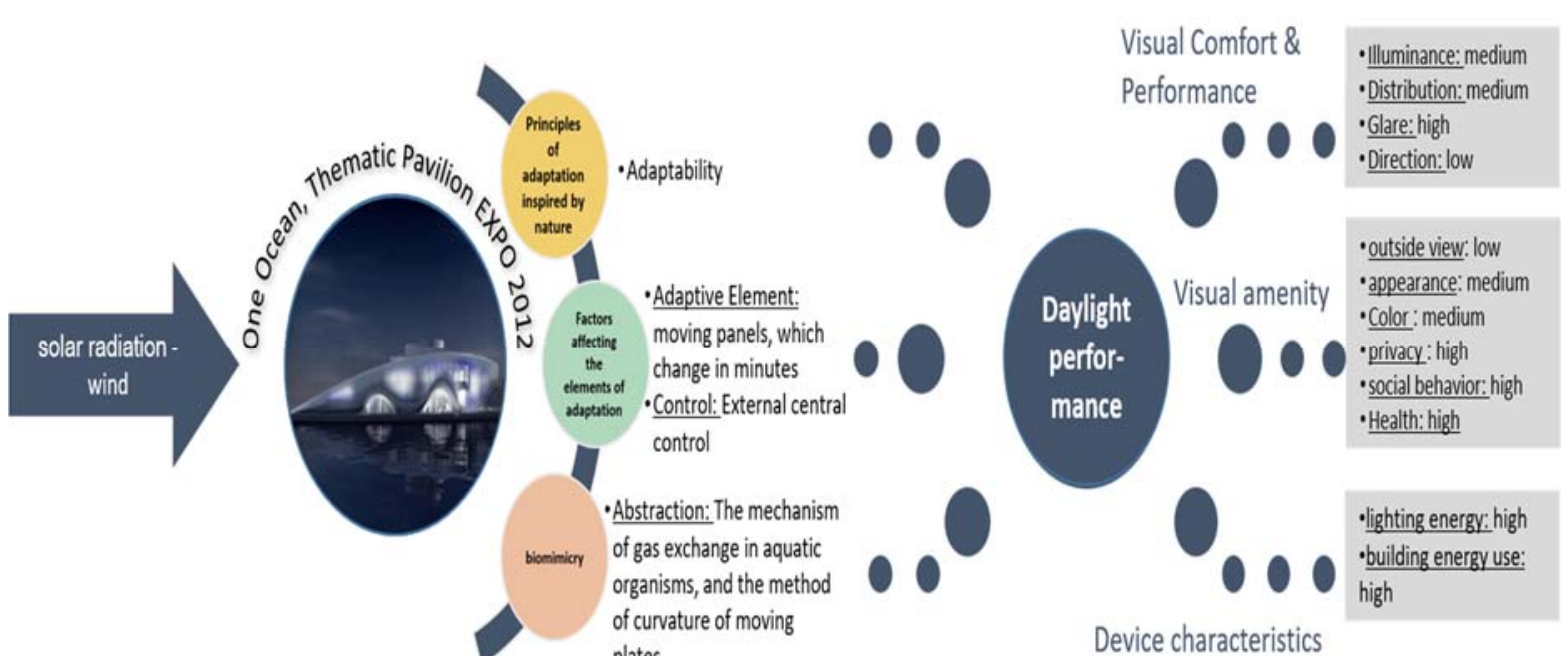

Figure 10. Daylight performance process in One Ocean Expo (Source: researcher)

Table 1. comparison between case studies how they achieved the bio-inspired adaptive façades

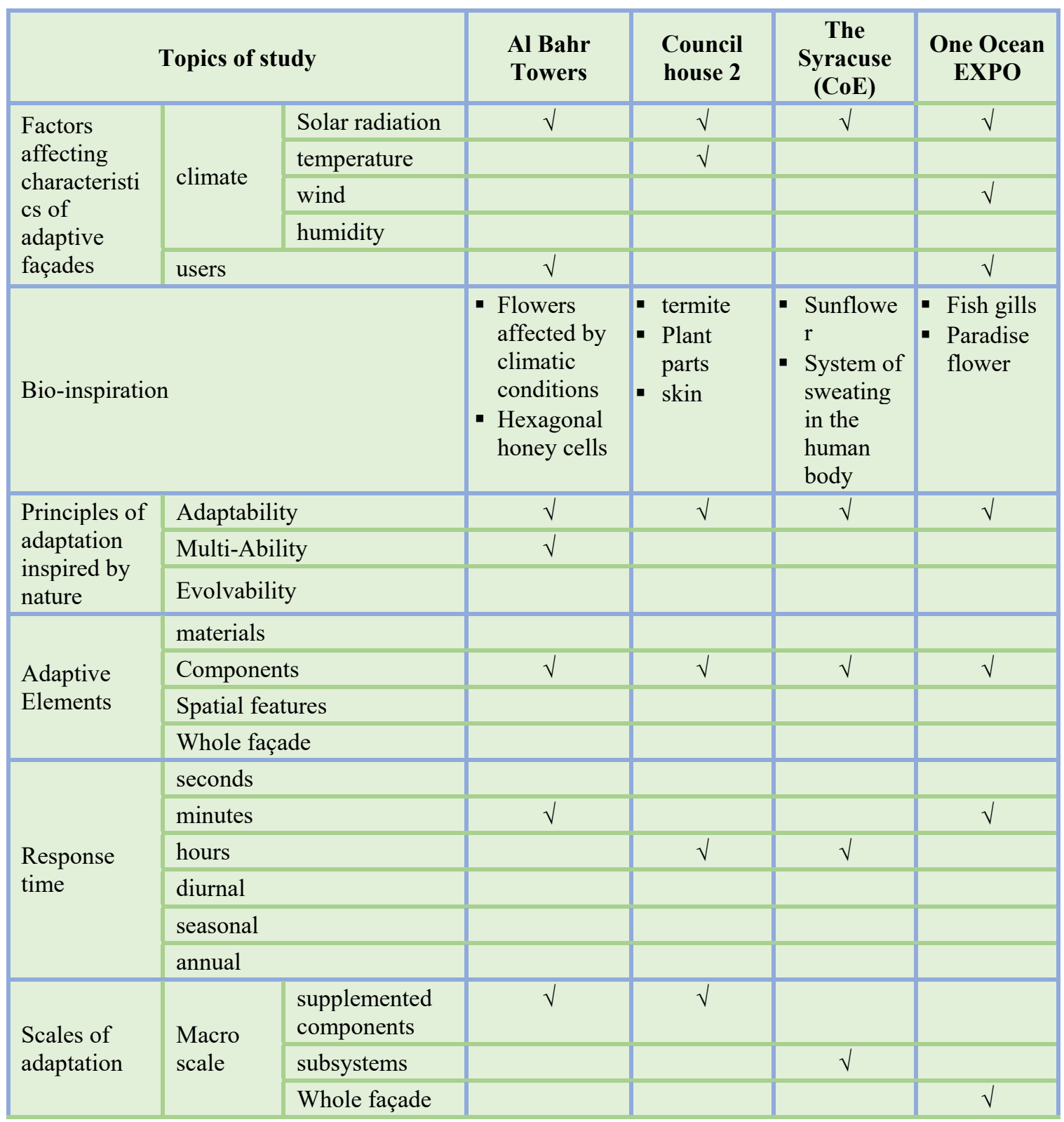




\begin{tabular}{|c|c|c|c|c|c|c|}
\hline & & Whole building & & & & \\
\hline & & Micro scale & & & & \\
\hline \multirow{3}{*}{$\begin{array}{l}\text { Typologies } \\
\text { of } \\
\text { movement }\end{array}$} & \multicolumn{2}{|c|}{$\begin{array}{l}\text { movement of rigid } \\
\text { architectural elements }\end{array}$} & $\sqrt{ }$ & $\sqrt{ }$ & $\sqrt{ }$ & \\
\hline & \multicolumn{2}{|c|}{$\begin{array}{l}\text { movement of deformable } \\
\text { architectural elements }\end{array}$} & & & & $\sqrt{ }$ \\
\hline & \multicolumn{2}{|c|}{ Changing in form and size } & & & & \\
\hline \multirow{4}{*}{ Control type } & \multirow{2}{*}{$\begin{array}{l}\text { Distribut } \\
\text { ed } \\
\text { control }\end{array}$} & Intrinsic control & & & & \\
\hline & & $\begin{array}{l}\text { Extrinsic } \\
\text { control }\end{array}$ & & & & \\
\hline & \multirow{2}{*}{$\begin{array}{l}\text { Central } \\
\text { control }\end{array}$} & Intrinsic control & & & & \\
\hline & & $\begin{array}{l}\text { Extrinsic } \\
\text { control }\end{array}$ & $\sqrt{ }$ & $\sqrt{ }$ & $\sqrt{ }$ & $\sqrt{ }$ \\
\hline \multirow{5}{*}{$\begin{array}{l}\text { Biomimicry } \\
\text { methods }\end{array}$} & \multicolumn{2}{|c|}{ Total mimicry } & & & & \\
\hline & \multicolumn{2}{|c|}{ Partial mimicry } & & $\sqrt{ }$ & & \\
\hline & \multicolumn{2}{|c|}{ Mechanics / physics } & $\sqrt{ }$ & & $\sqrt{ }$ & \\
\hline & \multicolumn{2}{|c|}{ abstraction } & $\sqrt{ }$ & $\sqrt{ }$ & $\sqrt{ }$ & $\sqrt{ }$ \\
\hline & \multicolumn{2}{|c|}{ inspiration } & & & & \\
\hline
\end{tabular}

Table 2. comparison between case studies about the daylighting performance

\begin{tabular}{|c|c|c|c|c|c|c|}
\hline \multicolumn{3}{|c|}{ Parameters } & \multirow{2}{*}{$\begin{array}{c}\text { Al bahr } \\
\text { towers }\end{array}$} & \multirow{2}{*}{$\begin{array}{c}\text { Council } \\
\text { house } 2\end{array}$} & \multirow{2}{*}{$\begin{array}{c}\text { The } \\
\text { Syracuse } \\
\text { (COE) } \\
\bullet\end{array}$} & \multirow{2}{*}{$\begin{array}{c}\text { One ocean } \\
\text { EXPO } \\
0\end{array}$} \\
\hline \multirow{12}{*}{$\begin{array}{l}\text { Daylighting } \\
\text { performance }\end{array}$} & \multirow{4}{*}{$\begin{array}{c}\text { Visual } \\
\text { Comfort \& } \\
\text { Performance }\end{array}$} & illuminance & & & & \\
\hline & & distribution & $\bullet$ & $\mathrm{O}$ & $\bullet$ & 0 \\
\hline & & glare & $\bullet$ & $\mathrm{O}$ & 0 & $\bullet$ \\
\hline & & direction & $\bullet$ & 0 & $\bullet$ & $\mathrm{O}$ \\
\hline & \multirow[t]{6}{*}{$\begin{array}{c}\text { Visual } \\
\text { amenity }\end{array}$} & $\begin{array}{l}\text { Outside } \\
\text { view }\end{array}$ & (1) & 1 & $\bullet$ & $\mathrm{O}$ \\
\hline & & appearance & 1 & (1) & $\bullet$ & 0 \\
\hline & & color & 1 & 0 & $\bullet$ & 0 \\
\hline & & privacy & 0 & $\bullet$ & $\mathrm{O}$ & $\bullet$ \\
\hline & & $\begin{array}{l}\text { Social } \\
\text { behavior }\end{array}$ & $\bullet$ & 1 & $\bullet$ & $\bullet$ \\
\hline & & Health & $\bullet$ & 0 & $\bullet$ & $\bullet$ \\
\hline & \multirow[t]{2}{*}{$\begin{array}{c}\text { Device } \\
\text { characteristics }\end{array}$} & $\begin{array}{l}\text { lighting } \\
\text { energy }\end{array}$ & $\bullet$ & $\bullet$ & $\bullet$ & $\bullet$ \\
\hline & & $\begin{array}{l}\text { Energy } \\
\text { used in } \\
\text { thermal } \\
\text { comfort }\end{array}$ & (1) & $\bullet$ & $\bullet$ & $\bullet$ \\
\hline
\end{tabular}

$$
\text { O low } \bigcirc \text { medium } \bullet \text { high }
$$


Table 3. comparison between case studies about the relation between adaptive façades and the daylighting performance

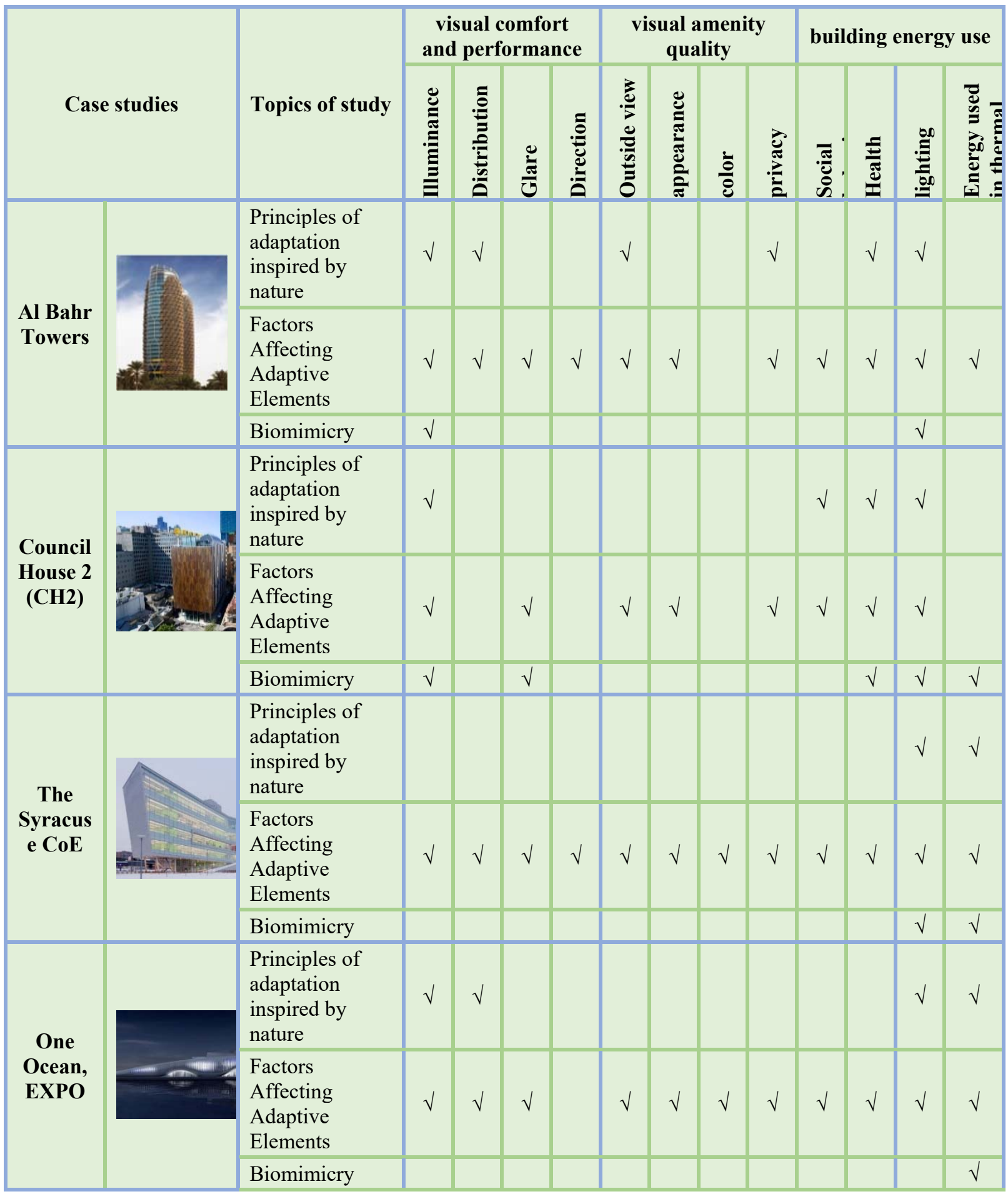

\section{Results}

1. The design of adaptive façades depends on the integration of many engineering sciences such as architecture, mechanical, structural, electrical, material sciences, biologists, chemists and others.

2. The design of adaptive façades between the building's personality and concept can be combined with the maximum efficiency of the building during its operation in terms of visual and thermal comfort and energy consumption.

3. Adaptability is the main and most prevalent principle in the design of adaptive climatic façades. The principle of evolution has not been seen in the projects under study because it takes several years or decades to be realized in buildings according to the ability of building systems to develop their properties according to external changes. 
4. Response time is a key factor in the design of kinetic patterns. For adaptation, design must create a relationship between external climatic factors and pattern movement to match the speed of climate changes in the external environment, such as by tracking the sun and considering it as a kinetic effect.

5. Patterns movement of adaptive façades adopt to the properties of components and adaptive elements, and adaptive materials in terms of their physical and mechanical properties.

6. Smart and adaptive materials have effect in their use as an adaptive component of the façades because of their physical, thermal and optical properties, and their great impact on architectural spaces in terms of visual and thermal comfort.

7. For biomimicry methods, the simulation of mechanical / physical nature and extraction is the most common. Total biomimicry, partial biomimicry of the weak effect of adaptation was not adopted. inspiration is the most difficult to apply and has not been used in the projects under study.

8. The daylight performance of buildings depends on the integration of three factors: the principles of natureinspired adaptation in the design of façades, the factors affecting elements of adaptation, and biomimicry.

9. Adaptive element is the most influential factor on the daylight performance variables: visual comfort and performance, visual amenity quality, and building energy use.

10. The efficiency of daylight performance increases as the principles of adaptation depend on it, the more biologically simulated the idea of solar radiation, and the more effective the adaptive element.

11. Solar radiation is the most influential factors on the façades, and have adaptive façades with adaptive shade systems are the most widespread.

12. The location difference, especially between the northern and southern hemispheres, affects the identification of appropriate treatments of façades.

13. In case studies, the adaptability principle was applied in $100 \%$.

14. Buildings did not achieve the level of the ecosystem as this level should be applied to the urban design rather than architectural

15. Principles of adaptation inspired by nature and factors affecting adaptive elements are the primary factor influencing the daylight performance of these buildings, more strongly than the principles inspired by nature.

16. Al Bahr Towers achieved $86 \%$ of the day lighting performance, while Council House 2 achieved a $69 \%$ of day lighting performance. The Syracuse University Research Centre achieved $92 \%$ of day light performance. The One Ocean Expo achieved a day performance of $83 \%$.

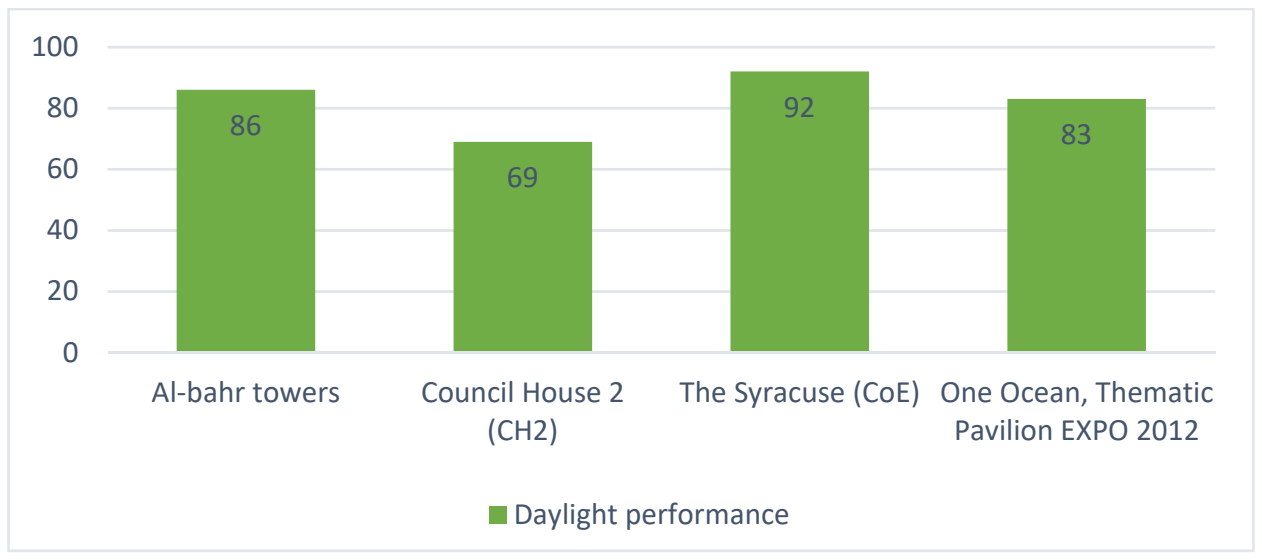

Figure 11. daylighting performance of case studies (source: researcher)

\section{CONClusion}

This paper aims to study the relation between the bio-inspired adaptive façades and the daylight performance inside these buildings. That depends on studying many factors: Principles of Adaptation inspired by nature in the design of façades, how to apply biomimicry and daylighting performance parameters. Then, comparing case studies depending on adaptive façades' design parameters then conducting a matrix to study the effect of adaptive façades design parameters and the daylighting performance

We conclude that the daylight performance of buildings depends on the biomimetic simulation and the elements influencing the adaptive element. The more efficient the daylight performance is, the more adaptive principles it relies on, the more the idea of biological simulation is more relevant to solar radiation, and the more it affects the adaptive element. 


\section{REFERENCES}

[1] L. Charlot, Smart Materials for the Realization of an Adaptive Building Component, Faculty of Architecture, Delft University of Technology, 2013.

[2] C. Lelieveld, Smart Materials for the Realization of an Adaptive Building Component, Faculty of Architecture, Delft University of Technology, 2013.

[3] M. López, R. Rubio, S. Martín and B. Croxford, "How plants inspire façades. From plants to architecture: Biomimetic principles for the development of adaptive architectural envelopes," Renewable and Sustainable Energy Reviews, vol. 67, pp. 692-703, January 2017.

[4] R. Loonen, M. Trčka, D. Cóstola and J. Hensen, "Climate adaptive building shells: State-of-the-art and future challenges," Renewable and Sustainable Energy Reviews, vol. 25, pp. 483-493, September 2013.

[5] R. Loonen, "Chapter 5: Bio-inspired Adaptive Building Skins," in Biotechnologies and Biomimetics for Civil Engineering, Springer, Cham, 2015, pp. 115-134.

[6] R. C. G. M. Loonen, Climate Adaptive Building Shells: What can we simulate, Architecture Building \& Planning, Eindhoven University of technology, 2010.

[7] H. Schnädelbach , "Adaptive architecture: A conceptual framework," 2010

[8] M.-M. Vogt, O. Schaeffer and M. Schumacher, Move: architecture in motion-dynamic components and elements, Birkhäuser Basel, 2010.

[9] Y. O. Elkhayat, "Interactive movement in kinetic architecture," Journal of Engineering Sciences, vol. 42, no. 3, pp. 816-845, May 2014.

[10] B. Bhushan, "Biomimetics: lessons from nature - an overview," The Royal Society, vol. 367, p. 1445-1486, april 2009.

[11] K. Konis and S. Selkowitz, Effective Daylighting with High-Performance Facades, 1 ed., Switzerland: Springer International Publishing, 2017.

[12] IEA, "Daylight in Buildings; A Source Book on Daylight Systems and Components, A Report of the International Energy Agency Solar Heating and Cooling, Task 21 / ECBCS Annex 29," the Lawrence Berkeley National Laboratory, Berkeley, 2000.

[13] A. Karanouh and E. Kerber, "Innovations in dynamic architecture, The Al-Bahr Towers Design and delivery of complex facades," Journal of Facade Design and Engineering, vol. 3, no. 2, pp. 185-221, Nov 2015.

[14] S. Attia, "Evaluation of adaptive facades: The case study of Al Bahr Towers in the UAE," QScience Connect, no. 2, 2017.

[15] L. Kaye, "World’s Largest Sun-Responsive Façade Shades Abu Dhabi’s Impressive Al Bahr Towers," 2211 2012. [Online]. Available: https://inhabitat.com/abu-dhabis-stunning-al-behar-towers-are-shaded-by-a-transforming-geometric-facade/. [Accessed 95 2018].

[16] M. Hoogland and P. Bannister, "COUNCIL HOUSE 2 (CH2) IN REVIEW," in Preloved Building Conference, Melbourne, 2013.

[17] J. Knippers, H. Jungjohann, F. Scheible and M. Oppe, "Bio-inspirierte kinetische Fassade für den Themenpavillon "One Ocean" EXPO 2012 in Yeosu, Korea," Bautechnik, vol. 90, no. 6, 2013.

[18] G. F. SHAPIRO, "Taking a Cue from Nature, a Kinetic Façade that Breathes Daylight," THE JOURNAL OF THE AMERICAN INSTITUTE OF ARCHITECTS, 2012. 